\title{
HUMANS ARE INTERPERSONAL BEINGS - WHY ISN'T SCIENCE COMMUNICATION INTERPERSONAL?
}

\author{
CURTIS MARTIN* \\ Ocean Frontier Institute \\ Dalhousie University, Halifax, NS
}

\begin{abstract}
Weak science communication coupled with misinformation and disinformation has resulted in major challenges for environmental decisionmakers, particularly in areas of climate change and marine renewable energy. Interpersonal communication strategies provide the means of facilitating a shift to two-way communication, as they encourage science conversations between communicators and citizens. Science communicators should make themselves more personally known to their audiences. They should communicate using shared stories and conversational language to enable them to relate better with their audiences. In addition, institutions, agencies, networks, and organizations should adapt and support the use of interpersonal strategies by their science communicators.
\end{abstract}

\section{INTRODUCTION}

Humans are interpersonal beings; our relational behaviour differentiates us from other social vertebrates (Shultz et al. 2011), and human communication evolved because of the need for cooperative action (Bohn 2016, Tomasello 2014). Speech and language are critical, but a significant part of communication is non-verbal (Phutela 2015). Non-verbal cues have great influence in the communication process, enhancing or detracting from the message (Hartley 1999, Phutela 2015). Communication is also dependent on social context and shared facts/beliefs (Bohn 2016, Clark 1996). In short, human communication is inherently interpersonal, so why isn't science communication interpersonal? This commentary will explore this question.

\footnotetext{
* Author to whom correspondence should be addressed: curtis.martin@dal.ca
} 


\section{THE CURRENT STATE OF SCIENCE COMMUNICATION}

The internet and social media tools have transformed the way people access information and are now the main information sources (National Science Board 2012, Purcell, Brenner, \& Rainie 2012). As of 2019, an estimated 4.4 billion people use the internet, with nearly 3.5 billion active on social media (We Are Social 2019). The internet and social media break down traditional communication barriers, facilitating near-instantaneous information sharing between people globally (Berger \& Milkman 2012, Faulkes 2014, Ferguson et al. 2014, Shiffman 2012, Sublet, Spring, \& Howard 2011, Wilson 2016, Winkless 2013). Although barriers still exist, the internet and social media are generally user-friendly, inexpensive, and accessible internationally (Peters, Dunwoody, Allgaier, Lo, \& Brossard 2014, Voytek 2017). People can engage in personal exchanges and form social networks (Connor et al. 2016, Mello \& Rodrigues 2012, Peters et al. 2014, Sublet et al. 2011, Voytek 2017, Wilson 2016).

Despite many benefits, broadly accessible information has also created problems. Perhaps the most prominent is socio-political misinformation (the spread of false information) and disinformation (deliberate sharing of false information to mislead). It is now easier than ever to perpetuate "truths" to a vast audience, and virtually any view on any issue can be "substantiated" with information if one searches hard enough. In some cases the proliferation of false (mis- or dis-) information has been particularly detrimental to environmentally-focused public policy issues, polarizing the public and dismantling trust in scientists and decision-makers (e.g., Aitken, Cunningham-Burley, \& Pagliari 2016, Arimoto \& Sato 2012, McCright, Dentzman, \& Charters 2013). False information sometimes has stalled crucial environmental policy on the international front, and can paralyze the prospect of citizens contributing to public discourse on global environmental issues.

The international "poster child" example of mis- and dis-information continues to be climate change. Although there is broad scientific consensus that climate change is real and human-caused, citizens have become polarized, with part of the population denying the human link to climate change, and others dismissing the issue entirely (Lawrence \& Estow 2017, Linden, Leiserowitz, Rosenthal, $\&$ Maibach 2017). Much of this polarization is along political lines, 
limiting progress on solutions (Benegal \& Scruggs 2018, Berinsky 2017, McCright \& Dunlap 2011, Nyhan, Reifler, \& Ubel 2013). A central cause has been the strategic dissemination of misinformation and disinformation regarding the scientific consensus surrounding climate change (Benegal \& Scruggs 2018, Oreskes \& Conway 2011). Such efforts have elevated falsehoods and altered public opinion on the cause of and solutions to climate change (Benegal \& Scruggs 2018). As a result, the proactive policies needed for climate change mitigation and adaptation are not being implemented at the necessary scale internationally. Many nations are failing to reach their own climate action targets (Cubasch et al. 2013).

Shifting to a local example, Nova Scotians have experienced similar challenges with the development of marine renewable energy. Atlantic Canada's Bay of Fundy has tidal energy potential among the highest in the world, with the prospect of reducing Nova Scotia's reliance on fossil fuels (Doelle 2009, Nova Scotia Department of Energy and Mines n.d.). Many stakeholders - including private interest groups, not-for-profits, and government - have been collaborating to capitalize on tidal energy availability for many years, but have faced numerous setbacks. In addition to technological issues, tidal energy proponents have been stymied by public opposition despite early calls for transparency in decision-making and effective citizen engagement (Doelle 2009, Quon 2013, Younger 2016). Local citizens continue to claim that environmental concerns are not being adequately addressed by developers, regardless of scientific evidence (MacLean 2017, The Canadian Press 2016). A local Fishermen's Association went so far as to initiate a legal battle with the province of Nova Scotia, applying for a judicial review of the province's decision to approve testing (MacDonald 2016, The Canadian Press 2016). The legal bid was later dismissed in court but the project has now stalled (Anon 2018). This marine renewable energy saga in the Bay of Fundy illustrated how ineffective science communication resulted in public opposition to environmental action, despite the use of scientific evidence in governance.

\section{DEFICITS AND DIALOGUES}

Why do we continue to see ineffective science communication on important environmental policy issues? In the past, much of this 
failure could be traced back to transmission-style models of science communication, in which it was assumed that citizens lacked knowledge and acted as passive receivers of information (Aitken et al. 2016, Irwin 2008, Salmon, Priestley, \& Goven 2017, Wakeford 2010). It is now understood that a dialogue model that emphasizes deliberative information exchanges between science communicators and citizens is more effective (Irwin 2008, Salmon et al. 2017, Wakeford 2010). The dialogue model promotes knowledge co-production, value-sharing, and the formation of trust relationships (Aitken et al. 2016, Corner, Markowitz, \& Pidgeon 2014, Dietz 2013, Salmon et al. 2017, Soomai, MacDonald, \& Wells 2013, Wynne 2006). Although the two-way model is now widely accepted as more effective for science communication with citizens, science communicators have struggled to implement two-way exchanges in practice (Collins et al. 2016, Kent 2013, Kent, Taylor, \& White 2003, Sweetser \& Lariscy 2008).

\section{MAKING SCIENCE COMMUNICATION PERSONAL}

Recent studies on science communication suggest that interpersonal communication can improve participation. Citizens are more likely to participate in exchanges with communicators they know (Fauville, Dupont, von Thun, \& Lundin 2015, Kent 2013, Lee \& VanDyke 2015, Martin 2018). "Face-to-face" interactions, including those taking place digitally through social media, can connect science communicators personally with their audiences (Cummins \& Cui 2014, Ferchaud, Grzeslo, Orme, \& LaGroue 2018, Labrecque 2014, Martin 2018). Citizens are also more likely to respond to scientific information if they find it relatable. Framing has contextualized the scientific information within public value systems by aligning messages with citizen interests (e.g., Hendricks 2017). However, framing can be expanded. For example, shared stories can connect members of the public with the science, making science communicators more approachable (Fauville et al. 2015, Hitlin \& Olmstead 2018, Martin 2018).

The language used for science communication is also important. More personal pronoun-rich language better reflects how citizens tend to communicate with one another. Using such language conveys authenticity and establishes trust between communicators and their 
audiences, leading to more effective communication (Martin 2018, Rubin \& Rubin 1985).

All of the communication strategies outlined above aid science communicators in establishing relationships with the public. This is crucial because relationships and two-way conversations act in a positive feedback loop. Once relationships are formed, a greater number of exchanges take place, strengthening existing relationships or leading to new ones (Martin 2018). Such two-way conversations are more likely to take place over extended periods, leading to more effective science communication efforts (Martin 2018).

It is important that science communicators seek out opportunities to apply these interpersonal strategies. Offline, this will likely require communicators to engage citizens in face-to-face meetings and not be limited to a single meeting. Additionally, interpersonal communication practices are easier to incorporate in less formal settings where conversational language, shared stories, and relationship building can take place (Martin 2018). Online, a growing avenue for such exchanges is social media, particularly Instagram. As a relatively intimate platform, Instagram is considered a safe space for personal exchanges, making it a tool through which science communicators can employ interpersonal communication strategies (Martin 2018).

\section{SYSTEMS FOR SCIENCE COMMUNICATORS}

Science communicators are not solely responsible for the shift, nor the difficulties in shifting, to an interpersonal two-way model of communication. Science communicators must be supported by institutions that encourage communicators to engage in conversations with their audiences. Communicators must be granted flexibility to apply interpersonal communication strategies to science communication. Too frequently, researchers (or research groups) are not encouraged to share scientific findings openly with citizens in non-expert formats. Researchers are sometimes actively discouraged from communicating science (e.g., Boyd 2018, Fox 2018, Gaston 2018). At a time when transparency is increasingly important to citizens, scientific information which mostly comes from publiclyfunded research is frequently locked behind paywalls. If science communication is to be more effective, scientific institutions must 
change the way in which they communicate with citizens. Only then will we create opportunities to bring about the environmental policy changes at a scale necessary to address issues such as climate change and maintain our well-being.

\section{REFERENCES}

Aitken, M., Cunningham-Burley, S. \& Pagliari, C. (2016). Moving from trust to trustworthiness: Experiences of public engagement in the Scottish Health Informatics Programme. Science and Public Policy, 43(5), 713-723. doi:10.1093/scipol/scv075.

Anon. (2018). Fundy tidal project leaves string of unpaid debts. (2018, September 14). $C B C$, Retrieved from

www.cbc.ca/news/canada/new-brunswick/tidal-energy-turbine-fundyminas-banruptcy-liquidation-ireland-claim-1.4822065.

Arimoto, T. \& Sato, Y. (2012). Rebuilding public trust in science for policy-making. Science, 337, 1176-1177. doi:10.1126/science.1224004.

Benegal, S.D. \& Scruggs, L.A. (2018). Correcting misinformation about climate change: the impact of partisanship in an experimental setting. Climatic Change, 148(1), 61-80. doi:10.1007/s10584-018-2192-4.

Berger, J. \& Milkman, K.L. (2012). What makes online content viral? Journal of Marketing Research, 49(2), 192-205. doi:10.1509/jmr.10.0353

Berinsky, A.J. (2017). Rumors and Health Care Reform: Experiments in Political Misinformation. British Journal of Political Science, 47(2), 241-262. doi:10.1017/S0007123415000186.

Bohn, M. (2016). Information and the evolution of human communication. In M. Burgin \& W. Hofkirchner (Eds.), Information Studies and the Quest for Transdisciplinarity (pp. 345-362). doi:10.1142/9789813109001_0011

Boyd, I. (2018). Be very cautious indeed. Research Fortnight, 532, 20-21.

Clark, H.H. (1996). Using language. Cambridge: Cambridge University Press.

Collins, K., Shiffman, D. \& Rock, J. (2016). How are scientists using social media in the workplace? PLOS ONE, 11(10), e0162680. doi:10.1371/ journal.pone.0162680.

Connor, P., Harris, E., Guy, S., Fernando, J., Shank, D.B., Kurz, T. \& Kashima, Y. (2016). Interpersonal communication about climate change: How messages change when communicated through simulated online social networks. Climatic Change, 136(3), 463-476. doi:10.1007/ s10584-016-1643-z.

Corner, A., Markowitz, E. \& Pidgeon, N. (2014). Public engagement with climate change: The role of human values. Wiley Interdisciplinary Reviews: Climate Change, 5(3), 411-422. doi:10.1002/wcc.269.

Cubasch, U., Wuebbles, D., Chen, D., Facchini, M.C., Frame, D., Mahowald, N. \& Winther, J.-G. (2013). Introduction. In T.F. Stocker, D. Qin, G.-K. Plattner, M. Tignor, S.K. Allen, J. Boschung, A. Nauels, Y. 
Xia, V. Bex \& P.M. Midgley, (Eds.), Climate change 2013: The physical science basis. Contribution of Working Group I to the Fifth Assessment Report of the Intergovernmental Panel on Climate Change. Cambridge and New York: Cambridge University Press.

Cummins, R.G. \& Cui, B. (2014). Reconceptualizing address in television programming: The effect of address and affective empathy on viewer experience of para-social interaction. Journal of Communication, 64(4), 723-742. doi:10.1111/jcom.12076.

Dietz, T. (2013). Bringing values and deliberation to science communication. Proceedings of the National Academy of Sciences, 110 (Supplement 3), 14081- 14087. doi:10.1073/pnas.1212740110.

Doelle, M. (2009). Role of Strategic Environmental Assessments in Energy Governance: A Case Study of Tidal Energy in Nova Scotia's Bay of Fundy. Journal of Energy \& Natural Resources Law, 27(2), 112-144. doi:10.1080/02646811.2009.11435210.

Faulkes, Z. (2014). The vacuum shouts back: Postpublication peer review on social media. Neuron, 82(2), 258-260. doi:10.1016/j.neuron.2014.03.032.

Fauville, G., Dupont, S., von Thun, S. \& Lundin, J. (2015). Can Facebook be used to increase scientific literacy? A case study of the Monterey Bay Aquarium Research Institute Facebook page and ocean literacy. Computers \& Education, 82, 60-73. doi:10.1016/j.compedu.2014.11.003.

Ferchaud, A., Grzeslo, J., Orme, S. \& LaGroue, J. (2018). Parasocial attributes and YouTube personalities: Exploring content trends across the most subscribed YouTube channels. Computers in Human Behavior, 80, 88-96. doi:10.1016/j.chb.2017.10.041.

Ferguson, C., Inglis, S.C., Newton, P.J., Cripps, P.J.S., Macdonald, P.S. \& Davidson, P.M. (2014). Social media: A tool to spread information: A case study analysis of Twitter conversation at the Cardiac Society of Australia \& New Zealand 61st Annual Scientific Meeting 2013. Collegian, 21(2), 89-93. doi:10.1016/j.colegn.2014.03.002.

Fox, F. (2018). The public is missing out, Research Fortnight, 532, 20.

Gaston, N. (2018). Uncertainty is healthy. Research Fortnight, 532, 21-22.

Hartley, P. (1999). Interpersonal Communication. New York: Routledge.

Hendricks, R. (2017). Communicating climate change: Focus on the framing, not just the facts. The Conversation, March 5th. Retrieved from theconversation.com/communicating-climate-change-focus-on-theframing-not-just-the-facts-73028.

Hitlin, P. \& Olmstead, K. (2018). The science people see on social media. Retrieved from www.pewinternet.org/2018/03/21/the-science-people-seeon-social- media/.

Irwin, A. (2008). Risk, science and public communication: Third order thinking about scientific culture. In M. Bucchi \& T. Brian (Eds.), Handbook of public communication of science and technology (pp. 199-212). London: Routledge. 
Kent, M.L. (2013). Using social media dialogically: Public relations role in reviving democracy. Public Relations Review, 39(4), 337-345. doi:10.1016/j.pubrev.2013.07.024.

Kent, M.L., Taylor, M. \& White, W.J. (2003). The relationship between web site design and organizational responsiveness to stakeholders. Public Relations Review, 29(1), 63-77. doi:10.1016/S0363-8111(02)00194-7.

Labrecque, L.I. (2014). Fostering consumer-brand relationships in social media environments: The role of para-social interaction. Journal of Interactive Marketing, 28(2), 134-148.

Lawrence, E.K. \& Estow, S. (2017). Responding to misinformation about climate change. Applied Environmental Education \& Communication, 16(2), 117-128. doi:10.1080/1533015X.2017.1305920.

Lee, N.M. \& VanDyke, M.S. (2015). Set it and forget it: The one-way use of social media by government agencies communicating science. Science Communication, 37(4), 533-541. doi:10.1177/1075547015588600.

Linden, S. van der, Leiserowitz, A., Rosenthal, S. \& Maibach, E. (2017). Inoculating the public against misinformation about climate change. Global Challenges, 1(2), 1600008. doi:10.1002/gch2.201600008.

MacDonald, M. (2016). Opponents of Bay of Fundy tidal power project ask judge to suspend testing. Global News, Sept 27th. Retrieved from globalnews.ca/news/2967134/opponents-of-bay-of-fundy-tidal-powerproject-ask-judge-to-suspend-testing/.

MacLean, A. (2017). 'Grinding Nemo' billboard aims to raise awareness about Bay of Fundy tidal turbines. Global News, Jan. 24th.

Retrieved from globalnews.ca/news/3203071/grinding-nemo-billboardmeant-to-turn-heads/.

Martin, C. (2018). "It Feels Like Engaging With a Friend": Using Interpersonal Communication Strategies to Encourage Science Conversations With Lay Audiences on Social Media (Master's graduate project report). Halifax: Dalhousie University.

McCright, A.M., Dentzman, K., Charters, M. \& Dietz, T. (2013). The influence of political ideology on trust in science. Environmental Research Letters, 8, 044029. doi:10.1088/1748-9326/8/4/044029.

McCright, A.M. \& Dunlap, R.E. (2011). The Politicization of Climate Change and Polarization in the American Public's Views of Global Warming, 2001-2010. The Sociological Quarterly, 52(2), 155-194. doi:10.1111/j.1533-8525.2011.01198.x.

Mello, D. \& Rodrigues, R. (2012). From constructivism to dialogism in the classroom. Theory and learning environments. International Journal of Educational Psychology, 1(2), 127-152.

National Science Board. (2012). Science and engineering indicators 2012. Washington, DC: National Science Foundation.

Nova Scotia Department of Energy and Mines. (n.d.). Top 10 things you need to know about tidal energy in Nova Scotia. Retrieved from energy. novascotia.ca/featured-stories/top-10-things-you-need-know-about-tidalenergy-nova-scotia. 
Nyhan, B., Reifler, J. \& Ubel, P.A. (2013). The hazards of correcting myths about health care reform. Med Care 51(2): 127-132.

Oreskes, N. \& Conway, E.M. (2011). Merchants of doubt: How a handful of scientists obscured the truth on issues from tobacco smoke to global warming. USA: Bloomsbury Press.

Peters, H.P., Dunwoody, S., Allgaier, J., Lo, Y.-Y. \& Brossard, D. (2014). Public communication of science 2.0: Is the communication of science via the "new media" online a genuine transformation or old wine in new bottles? EMBO Reports, 15(7), 749-753. doi:10.15252/embr.201438979.

Phutela, D. (2015). The importance of non-verbal communication. The IUP Journal of Soft Skills, 9(4), 43-49.

Purcell, K., Brenner, J. \& Rainie, L. (2012). Search engine use 2012. Washington, DC: Pew Internet \& American Life Project.

Quon, A. (2018). Cape Sharp Tidal turbine was 'damaged beyond repair' in September. Global News, November 13th.

Retrieved from globalnews.ca/news/4644316/cape-sharp-tidal-turbinedamaged/.

Rubin, A.M. \& Rubin, R.B. (1985). Interface of personal and mediated communication: A research agenda. Critical Studies in Mass Communication, 2(1), 36-53. doi:10.1080/15295038509360060.

Salmon, R.A., Priestley, R.K. \& Goven, J. (2017). The reflexive scientist: An approach to transforming public engagement. Journal of Environmental Studies and Sciences, 7(1), 53-68. doi:10.1007/s13412-015-0274-4.

Shiffman, D.S. (2012). Twitter as a tool for conservation education and outreach: What scientific conferences can do to promote live-tweeting. Journal of Environmental Studies and Sciences, 2(3), 257-262. doi:10.1007/ s13412-012-0080-1.

Shultz, S., Opie, C. \& Atkinson, Q.D. (2011). Stepwise evolution of stable sociality in primates. Nature, 479(7372), 219-222. doi:10.1038/ nature10601.

Soomai, S.S., MacDonald, B.H. \& Wells, P.G. (2013). Communicating environmental information to the stakeholders in coastal and marine policy-making: Case studies from Nova Scotia and the Gulf of Maine/ Bay of Fundy region. Marine Policy, 40, 176-186. doi:10.1016/j.marpol.2013.01.017.

Sublet, V., Spring, C. \& Howard, J. (2011). Does social media improve communication? Evaluating the NIOSH science blog. American Journal of Industrial Medicine, 54(5), 384-394. doi:10.1002/ajim.20921.

Sweetser, K.D. \& Lariscy, R.W. (2008). Candidates make good friends: An analysis of candidates' uses of Facebook. International Journal of Strategic Communication, 2(3), 175-198. doi:10.1080/15531180802178687.

The Canadian Press. (2016). Nova Scotia fishermen head to court to stop Bay of Fundy tidal power project. Global News, August 26.

Retrieved from globalnews.ca/news/2905270/nova-scotia-fishermen-headto-court-to-stop-bay-of-fundy-tidal-power-project/.

Tomasello, M. (2014). A natural history of human thinking. London: Harvard University Press. 
Voytek, B. (2017). Social media, open science, and data science are inextricably linked. Neuron, 96(6), 1219-1222. doi:10.1016/j. neuron.2017.11.015.

Wakeford, T. (2010). Third-order thinking in science communication. Japanese Journal of Science Communication, 7, 87-93.

We Are Social. (2019). Digital in 2018.

Available from wearesocial.com/global-digital-report-2019. 2019.

Wilson, M. (2016). The good news about science communication in the social media age. Fisheries, 41(9), 506-506. doi:10.1080/03632415. 2016.1220224.

Winkless, L. (2013). Science and the \#hashtag: Laurie Winkless considers the impact social media is having on the scientific community. Materials Today, 16(1), 2-3. doi:10.1016/j.mattod.2013.01.003.

Wynne, B. (2006). Public engagement as a means of restoring public trust in science - hitting the notes, but missing the music? Public Health Genomics, 9(3), 211-220. doi:10.1159/000092659.

Younger, A. (2016). Nova Scotia needs to fully engage with stakeholders on tidal energy. Huffington Post, December 12.

Retrieved from www.huffingtonpost.ca/andrew-younger/tidal-energynova-scotia_b_13535578.html. 